\title{
AN EXPERIMENTAL STUDY OF THE LINGUAL CONSCIOUSNESS OF UKRAINIANS AND RUSSIANS (DYNAMIC ASPECT)
}

\author{
Diana Terekhova \\ dterekhova@ukr.net \\ Kyiv National Linguistic University, Ukraine
}

Received June 12, 2018; Revised June 22, 2018; Accepted June 28, 2018

\begin{abstract}
The study of the lingual consciousness of various ethnic group representatives does not lose its topicality in psycholinguistic investigation for decades. During the period of the formation and development of psycholinguistics, scientis ts have gained considerable experience in doing associative experiments, the results of which are reflected in associative dictionaries and individual scientific investigations. This material is valuable in several aspects of the investigation in particular as an object of the study of the lingual consciousness of the certain language speakers for the duration of the experiment; in the comparable aspect for the identification of common and distinguishing features in the lingual consciousness of the representatives of different ethnic groups as well as to find out the changes in the lingual consciousness of the repre sentatives of a certain ethnic group according to the experimental data received at a certain time interval, etc. The article focuses on revealing the dynamics of the lingual consciousness of two East Slavic language speakers - Ukrainian and Russian. The material resulted from a series of experiments recorded in lexicographic psycholinguistic works and self-conducted studies held in 2000 and in 2012 representing the changes in the corresponding fragments of the world image of the Ukrainians and Russians.
\end{abstract}

Keywords: world image, linguistic consciousness, associative experiment, association, associative field, associative gestalt.

Терехова Діана. Експериментальне дослідження мовної свідомості українців та росіян (динамічний аспект).

Анотація. Вивчення мовної свідомості представників різних етносів не втрачає своєї актуальності у психолінгв істичних розвідках останніх десятиліть. За період становлення та розвитку психолінгвістики науковці накопичили значний досвід проведення асоціативних експериментів, результати яких відбито в асоціативних словниках та окремих наукових розвідках. Цей матеріал є цінним у кількох аспектах дослідження, зокрема як об'єкт вивчення мовної свідомості носіїв певної мови саме на період проведення експерименту, у зіставному аспекті для виявлення спільних та відмінних рис у мовній свідомості представників різних етносів, а також для з'ясування змін у мовній свідомості преставників певного етносу за експериментальними даними, отриманими на певному часовому проміжку тощо. Отже статтю присвячено виявленню динаміки мовної свідомості представників двох східнослов'янських народів. Матеріалом обрано результати експериментів, зафіксованих у лексикографічних психолінгв істичних працях, та власноруч проведених експериментальних досліджень 2000 та 2012 років, що репрезентує зміни у відповідних фрагментах образу св іту українців та росіян.

Ключові слова: образ світу, мовна свідомість, асоціативний експеримент, асоціачія, асоціативне поле, асиіативний гештальт.

(C) Terekhova, Diana, 2018. This is an Open Access article distributed under the terms and conditions of the Creative Commons Attribution 4.0 International Licence (http://creativecommons.org/licenses/by/4.0).

East European Journal of Psycholinguistics, 5(1), 92-110. https://doi.org/10.5281/zenodo.1436306 


\section{Introduction}

Both native and foreign scientists actively continue studying the lingual consciousness as an object of psycholinguistics over the past few decades. Traditional methods for studying the lingual consciousness and associative experiments, which were conducted among speakers of different languages mainly from the second half of the last century, made it possible to accumulate a significant amount of material and compile associative dictionaries on its basis. Such lexicographic works are valuable for the study of dynamic processes occurring in the lingual consciousness of certain ethnic group members for a certain period of time.

Consequently, the paper proves the necessity to define the role of changes in the Ukrainian and Russian native speakers' lingual consciousness that have occurred over the past fifty years, which were characterized by radical changes in all spheres of life connected primarily with the formation of the independent states on the postSoviet area. The results of the study are valuable in the aspect of their detecting the dynamics in the fragments of the world images, expressing the meaning of each word in every language in order to get to know the national and cultural originality of the lingual consciousness as well as preventing the intercultural communication problems.

The permanent scientists' interest in the language consciousness changes is represented in the analysis of the recent researches. A significant part of psycholinguistic works focuses on the study of the dynamics of the lingual consciousness changes in ontogenesis (for example, Ababkova, 2007; Holdyn, 2005, 2007; Holdyn, Sdobnova, 2006; Sdobnova, 2012; Ufimtseva, 1983, 2011). Some works deal with the changes of the lingual consciousness of different ethnic group representatives (for instance, Ufimtseva, 2000; Kornieiev, 2007; Saburkina, Sonin, 2005; Yudina, Chernykh, 2016 - on the material of the Russian language; Terekhova, 2006, 2007 a, 2007 b, 2008, 2017, 20018 - on materials of the East Slavic languages; Balandina, 2013 - on the material of the Russian and English languages; Volkovynska, 2018 - on the material of the English language; Moldaliiev, Sandybaieva, 2003 - on the material of the Kazakh language; Chzhao Tsiuie, 2013 - on the material of the Chinese language). The article substantiates the dynamics of the lingual consciousness of representatives of the Ukrainian and Russian peoples from the 1970s to 2012.

In linguistic studies, земля (earth) was the object of study mainly on the material of a particular language (see: Kalinuk, 2010; Ogar, 2014 - in the Ukrainian language; Petrova, 2009; Pimanova, 2008; Semenov, 2009; Frolova, 2012; Chzhao Siuts in, 2010 - in the Russian language, Litvinova, 2006 - in English language; Khustundinov, 2009 - in the Tatar language) as well as in comparison with other languages (see: Ghen Tse, 2015 in the Russian and Chinese languages, Zuraiev, 2012 in Russian and French languages, Kryvalova, 2008 in Russian and German languages). In the above-mentioned works, земля (earth) is mostly studied as a part of opposition НЕБО - ЗЕМЛЯ (SKY - EARTH) (Ghen Tse, A. O. Ogar, Siutsin Chzhao), or triads СВІТЛО - НЕБО - ЗЕМЛЯ (LIGHT - SKY - EARTH) 
(O. Krivalova, N. Pimanova), СОНЦЕ - ЗЕМЛЯ - ЛУНА (SUN - ЕАRTН MOON) (V. Zuraiev), as a part of concepts of the main elements: ВОДА, ПОВITРЯ, ЗЕМЛЯ, ВОГОНЬ (WATЕR, AIR, ЕARTH, FIRE) (S. Litvinova, L. Frolova), but some works are devoted to studying of the concept ЗЕМЛЯ (EARTH) (A. Semenov, D. Khustundinov) or the image ЗЕМЛЯ (EARTH) (N. Kalyniuk).

Among the psycholinguistic scientific studies such researches of the wordstimulus ЗЕМЛЯ (ЕАRТН) are made by M. Muravytska, N. Ufimtseva and others. The nationaly cultural specificity of the perception of this stimulus and its correlates in the Russian and Belarusian languages was also disclosed in one of our previous works (see Terekhova, 2008), however, changes in the linguistic consciousness of representatives of the East Slavic languages in the corresponding fragments of the image of the world, that took place over the past thirty years, have not been investigated, therefore, we are trying to solve this issue in this work.

\section{Methods}

The aim of the article is to analyze the associative fields of the LAND / LAND stimuli in the Ukrainian and Russian languages in order to detect changes in the corresponding fragments of the world image by the respective language speakers.

General scientific, special linguistic and psycholinguistic methods, in particular descriptive, comparative, mathematical (quantitative calculations), free word association test and others are used in this paper.

Among the sources of the study were lexicographic works ("Dictionary of associative norms of the Russian language" (1977), "Dictionary of associative norms of the Ukrainian language" (1979), "Slavic associative dictionary: Russian, Byelorussian, Bulgarian, Ukrainian" (2004), and word association tests conducted in 2000 and 2012 in Ukraine and Russia. The respondents were students of higher educational establishments of these countries (one hundred representatives from each group of these peoples).

\section{Results and Discussion}

The study of the lingual consciousness of closely related language carriers, who have had significant common periods of life in the historical and cultural context, requires careful attention and well-considered characteristics in order to understand the common and specific features and explain their causes.

Therefore, before analyzing the images of the lingual consciousness that convey the meaning of peculiar words, it is necessary to consult some lexicographic sources.

The etymological dictionaries of the Ukrainian and Russian languages testify to the identical Common Slavic roots of the words земля / земля (land) in two closely related languages.

According to the explanatory dictionaries of the contemporary Ukrainian and Russian languages, the word земля is polysemantic and most of its meanings coincide (see Table 1). 
Consequently, the explanatory dictionaries record a significant coincidence in the meaning of the words земля / земля in both languages, in particular it means: 1) the third large planet from the Sun;2) the upper layer of the crust, soil; 3) the substance of dark brown colour which is the part of the earth's crust; 4) land; 5) country, land, state. In the Russian language this word has still the meaning of "administrative-territorial unit" denoting the regions in some parts of the country. Thus, the lexicographic meaning of these words in both languages is close, but not identical.

\section{Compared meanings of the word земля (land) in the Ukrainian and Russian languages}

\section{Ukrainian}

\section{ЗЕМЛЯ (LAND)}

1. The third from the Sun (distance) big planet that rotates around its own axis as well as around the Sun.

2. The upper layer of the Earth crust, soil.

3. Substance of dark reddish brown color thas is a part of the Earth's crust. 4. Land as contrasted to water or air.

5. Ground cultivating and using for growing plants.

6. Country, region, state.

7. the Big Land; to the back of beyond - too far away; the land of promis (Dictionary of the Ukrainian language: 557)

\section{Russian}

1. The third from the Sun (in order)

big planet that goes around its own axis as well as around the Sun.

2. Land as contrasted to water or air.

3. The upper lay of the Earth crust, soil, ground, surface.

4. Substance of dark reddish brown color thas is a part of the Earth's crust.

5. Country, state, any big territory of the Earth.

6. Territory with farming and hunting and acreage owned or rented by someone.

7. In Austria and Germany: administrative territory, entity.

8. bow to the ground 1) deep bow to the ground, prostration; 2) whom, deep respect. (Ozhegov, Shvedova)

In the traditional, ancient perception of Ukrainians and Russians, the word земля is interpreted as the highest fundamental value, a shrine, a "mother" who needs protection and careful attitude towards it. The word земля is associated with many beliefs of people, rituals since pre-Christian and Christian times. And the attitudes towards it are recorded in oral folk art, in particular mythology, proverbs and sayings. Being sacred, this word has long time history. 
A famous Ukrainian linguist $V$. Zhaivoronok noted that since the ancient times in Ukrainian ethno-culture "... the land was refered to as a 'mother' giving birth to all that is needed for life and it takes away everything after death. According to the Bible, in the beginning our Lord created the heavens and the earth separating the firmament from the water; Lord called the dry land as "earth" and the gathering together of the waters He called as 'Sea'. Since pre-Christian times people have traditionally worshiped the earth so there are many epithets in the language: God's, pious, holy, native, sacred, generous, rich. The earth acts as a personified creature in the popular imagination so "you can't hit the earth with a stick, because it hurts, and this is a great sin". In the case of harm, the earth can part and absorb an evil or a sinner" (Zhaivoronok, 2006:243). It is said the earth is "the last man's shelter" during his /her life.

The earth plays an vital role in Christian beliefs. There are two important religious holidays in Christianity: The Entry of the Most Holy Theotokos into the Temple, and The Annunciation. It is believed that during these days God blesses the earth and the nature awakens from its winter sleep at this time. People are allowed to work on earth after Annunciation. The earth symbolizes wealth and fruitfulness. Giving a birth to a child a woman wished the newborn: "To be as rich as a land and strong like water". The earth is considered to be as a symbol of oath ... therefore, swearing people eat the earth or kiss it... No one tolerates the bloodshed, especially the innocent on the holy earth (also according to the Bible) (Zhaivoronok, 2006:244).

Land as an object of agricultural activity embodies peasant's eternal dreams "to have their own land, field. The souls of Ukrainian people tend to grow a lot of grain, therefore from the remotest times they work on the ground ...It is said "Peasant who has no land is like fish without water" (Zhaivoronok, 2006:244).

The word земля in its meaning 'country, land, state' was originally perceived as something native, the best thing, the land-mother: "The native land is like mother and a strange one - a stepmother" (Zhaivoronok, 2006:245).

From time immemorial the land in the Russian cultural tradition was also considered a sacred object of the universe. People treated the land as an object of worship. It was like a breadwinner for every family. Peasants cultivated the crops. Men defended their native places against the invaders. People swore on the ground. Even when they passed away it was obvious that they were buried in it.

In his work "Constants: Dictionary of the Russian Culture" (2001) on analyzing the concept of native land / ridna zemlia, Yu. Stepanov distinguishes between the native land and the whole Earth - our common home where we come when we are born as inhabitants of the world (Stepanov, 2001:170).

Defining the structure of this concept, Stepanov confirms that according to M. Prishvin's it can be clearly defined in the Russian mentality as follows: "a) a pain for his or her land; b) natural wealth; c) the land itself; d) the close person; e) the 'crowned' nature; e) the native word" (Stepanov, 2001:170).

Stepanov presents the following features of this concept referring to V. Klyuchevsky's works. He began the description of the country history with the 
characteristics of territory, climate and soil - in particular, from the earth: "describes its main characteristics - the spacious terrain that brings Russia closer to Asia and the three main elements are the forest, the steppe, the river" (Stepanov, 2001:172). Much attention is paid to M. Berdyaev's philosophy as he also emphasizes the importance of the geographical factors and the country boundlessness. The philosopher notices that a Russian man "relies too much on the Russian land $<\ldots>$ almost equals ... his mother-land with the Mother of God and relies on her protection" (Stepanov, 2001:174). Obviously, Yu. Stepanov emphasizes the religious attitude towards his country and land as being a mother.

Peoples' traditional imagination about the fundamental principles of the universe is reflected in their mentality and contemporary representatives' lingual consciousness. The psycholinguistic methods of research, in particular associative experiments help to identify the world image features that are expressed by certain words. It should be noticed that the number of respondents who had participated in these experiments differed much so the associative fields are also different in their scope. At the same time, it seems quite possible to find out the main tendencies in association and the changes in the structure of associative fields that have occurred in the speakers' lingual consciousness of a certain language for a certain time interval.

On comparing the associative field nucleus, the number of reactions is given in figures, as it is usually presented in the dictionary articles and during the general analysis of associative fields the interpretation results are given in percentage for greater objectivity.

The comparison of the nucleus of the associative stimulus fields ЗЕМЛЯ / ЗЕМЛЯ showed the following most frequent reactions of respondents (see tables 2, 3):

Table 2

\section{The nucleus of the associative fields of the stimulus ЗЕМЛЯ (LAND) in the Ukrainian language}

\begin{tabular}{|c|c|c|c|c|}
\hline \# & $\begin{array}{l}\text { Dictionary edited } \\
\text { by Butenko N.P. } \\
\text { (1979: 34-35), } \\
989 \text { respondents }\end{array}$ & $\begin{array}{l}\text { Slavic associative } \\
\text { dictionary (2004: } \\
\text { 123-125), } 478 \\
\text { respondents }\end{array}$ & $\begin{array}{l}\text { Experiment } \\
(2000), \\
100 \\
\text { respondents }\end{array}$ & $\begin{array}{l}\text { Experiment } \\
\text { (2012), } \\
100 \text { respondents }\end{array}$ \\
\hline 1. & чорна (196) & рідна (46) & планета (11) & кругла (8) \\
\hline 2 & кругла (88) & кругла (38) & грунт (7) & чорна (8) \\
\hline 3 & родюча (62) & родюча (24) & кругла (6) & поле (6) \\
\hline 4 & рідна (39) & планета (23) & мати (5) & планета (5) \\
\hline & багата (38) & чорна (21) & урожай (4) & хліб (5) \\
\hline & $\begin{array}{l}\text { Mamu (30) } \\
\text { a Terekho va }\end{array}$ & життя (14) & & Invнm (4) \\
\hline & трунт (24) & грунт (11) & & \\
\hline
\end{tabular}

During late 1970s, the land was primarily associated with the fertility of Ukrainian "chornozems" in the lingual consciousness of Ukrainians. These 
"chornozems" is the key to successful agricultural activity, (LAND (ЗЕМЛЯ) чорна (black) (196), родюча (fertile) (62), багата (rich) (38), тепла (warm) (25), tрyнm (soil) (24)) being traditional for the peasants of this region since ancient times.

The association of the ЕАRTН (ЗЕМЛЯ) - кругла (round) (88) points out to another direction of the association - perception of the Earth as a planet, a space object.

The connection between the Earth and the native Land can be traced in the reactions of LAND (ЗЕМЛЯ) - рідна (native) (39), мати (mother) (30), the latter of which reflects the eternal attitude of Ukrainians to the land as the closest person, the "mother" who gives life to everything.

At the turn of the $20^{\text {th }}-21^{\text {st }}$ centuries there is a certain shift of emphasis in the perception of the stimulus of the LAND in the lingual consciousness of the representatives of the Ukrainian ethnos. Thus, according to the experiment of the year of 2000, the land was mainly perceived by respondents as a space object (the ЕARTН (ЗЕМЛЯ) - планета (planet) (11), кругла (round) (6)); its agricultural purpose was somewhat less relevant but still important (LAND (ЗЕМЛЯ) - tрунт (soil) (7), урожай (сrop) (4)) as well as traditional ethnocultural conception in the form of the mother (LAND (ЗЕМЛЯ) - мати (mother) (5)).

In accordance with the Slavic associative dictionary (2004) this tendency is also observed in the associative field nucleus of the word-stimulus LAND (ЗЕМЛЯ): among the frequency responses its perception as a planet is the most perceptible (the ЕARTH (ЗЕМЛЯ) is кругла (round) (38), планета (planet) (23), велика (large) (13)); LAND (ЗЕМЛЯ) is important as an object of the agricultural activity (LAND (ЗЕМЛЯ) - велика (big) (24), чорна (black) (21), tрунт (soil) (11)) and the most frequent reaction to the word LAND (ЗЕМЛЯ) - pidна (native) (46) focuses on the attitude to the land as a native land.

In accordance with the results of the Experiment in 2012 (similar to those that the respondents of 1970s have) the reactions of the associative field nucleous reflect the Ukrainian respondents' perception of the stimulus LAND (ЗЕМЛЯ) mainly as an activity of peasants (LAND (ЗЕМЛЯ) - чорна (black) (8), nоле (field) (6), хліб (bread) (5), tрунт (soil) (4)) and then in the planetary sense (EARTН (ЗЕМЛЯ) кругла (round) (8), планета (planet) (5)). It should be noted that the experimental data of 2004 and 2012 showed that the nuclei of these associative stimulus fields of the word LAND (ЗЕМЛЯ) do not contain mother associations. They have shifted towards the fields of peripheral zone that testifies to a decrease in the relevance of this direction of association.

A complete survey of the main directions of association is given below in Tables 4, 5 that are based on the analysis of associative fields in general.

Among the Russian respondents in 1970s, the EARTH was primarily concerned with their native land, the place where the person was born and raised (LAND - родная (native) (66)). 
Table 3

The nucleus of the associative fields of the stimulus ЗЕМЛЯ (LAND) in the Russian language

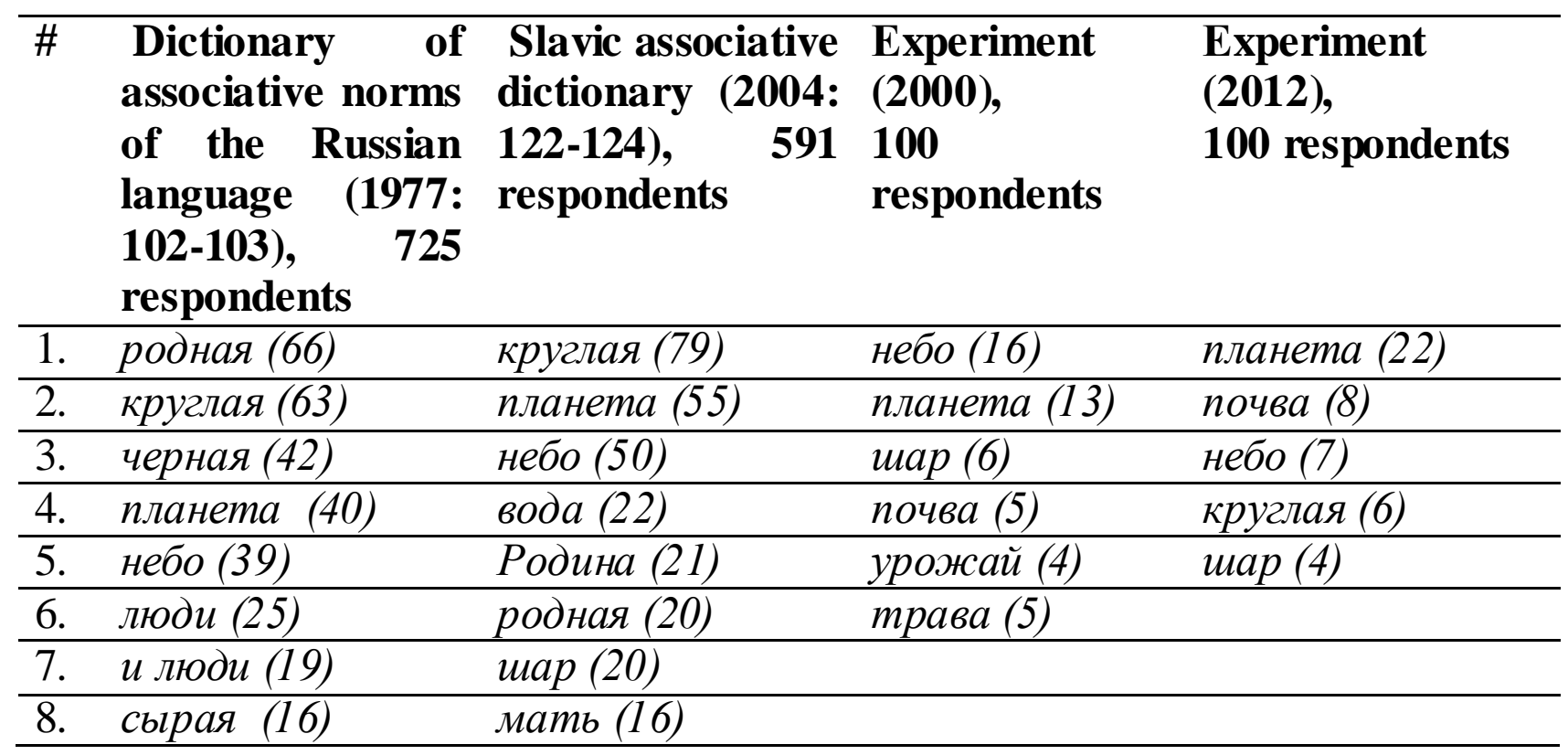

Numerous associations are those that refer to another direction of them - the perception of the earth as a planet (the ЕARTH (ЗЕМЛЯ) - круглая (round) (63), планета (planet) (40)) in opposition to the sky (the EARTH (ЗЕМЛЯ) - небо (Heaven) (39)).

The vision of the earth as a ground is appeared in the association of LAND (ЗЕМЛЯ) - черная (black (42)) and it is significant among the Russian respondents.

The EARTH reactions - люди (реорle) (25), і люди (and people) (19) testify to the indissoluble connection when the earth is connected with the people who live and work on it. The nucleous of the associative field of this stimulus also includes the association the ЕARTH (ЗЕМЛЯ) - сырая (raw) (16) which is obviously a reflection of the ancient image of LAND Mother - personified image of Land known not only in Russian but also in Slavonic mythology.

In accordance with the experimental data of 2000 the stimulus LAND (ЗЕМЛЯ) was primarily perceived as an opposition to the SKY (LAND (ЗЕМЛЯ) - небо (sky) (16)) which is a stereotyped image and is based on ancient mythological notions of the universe. However, by that time the total number of associations of the nucleus of the associative stimulus field LAND (ЗЕМЛЯ) has had the predominant perception of the Earth as a planet (ЕARTH (ЗЕМЛЯ) планета (planet) (13), шар (layer) (6)).

The agricultural aspect (LAND - почва (soil) (5), урожай (crop) (4)) was the next important position.

Similar tendencies in the ways of association were retained among Russian respondents and in subsequent years, for example, in 2004 (LAND (ЗЕМЛЯ) круглая (round) (79), планета (planet) (55), родная (layer) (20)) and in 2012 (LAND 
(ЗЕМЛЯ) - планета (planet) (22), круглая (round) (6), шар (layer) (4)); the most frequent associations represent the perception of the Earth on a planetary scale.

In order to fully characterize the nuclei of associative fields, some differences must also be added, in particular, the updating of the directions of association among Russian respondents referring to data in 2004 and taking into consideration LAND (ЗЕМЛЯ) identification with their native land (LAND - Pодина (Motherland) (21), родная (native) (20), mother (LAND (ЗЕМЛЯ) - мать (mother) (16)) in comparison with other variants (LAND (ЗЕМЛЯ) - вода (water) (22)).

The perception of the land in the sense of "soil" is also important (the EARTH (ЗЕМЛЯ) - почва (soil) (8)) among respondents who were surveyed in 2012.

Thus, in the nuclei of the associative fields of stimuli LAND (ЗЕМЛЯ) / LAND (ЗЕМЛЯ) in the Ukrainian and Russian languages the main directions of association are revealed. They are relevant to a greater or lesser degree for respondents at different time intervals (from 1970s of the $20^{\text {th }}$ century to 2012). These trends are also manifested in the analysis of the associative fields in general, however, their degree of relevance may change which is fixed in numerical indixes in the general rating. The associative gestalt is used for the analysis of associative fields, the essence of which is repeatedly stated in the references and our previous works. The results of this methodology are presented in Tables 4 and 5.

Table 4

The gestalt structure of the associative fields of the stimulus ЗЕМЛЯ (LAND) according to dictionaries and free word association tests in the Ukrainian language

\begin{tabular}{|c|c|c|c|c|c|}
\hline \# & Gestalt areas & $\begin{array}{l}\text { Dictionary } \\
\text { edited by N. } \\
\text { Butenko } \\
(1979: \text { 34-35), } \\
989 \text { respon- } \\
\text { dents, } \\
\text { per cent }\end{array}$ & $\begin{array}{l}\text { Slavic } \\
\text { associative } \\
\text { dictionary } \\
(2004: \quad 123- \\
125), 478 \text { res- } \\
\text { pondents, } \\
\text { per cent }\end{array}$ & $\begin{array}{l}\text { Experiment } \\
2000 \text {, } \\
100 \text { respon- } \\
\text { dents, } \\
\text { per cent }\end{array}$ & $\begin{array}{l}\text { Experiment } \\
2012 \text {, } \\
100 \text { respon- } \\
\text { dents, } \\
\text { per cent }\end{array}$ \\
\hline 1 & 2 & 3 & 4 & 5 & 6 \\
\hline 1 & Characteristics & 68 & 45 & 11 & 21 \\
\hline 2 & Soil & 5 & 4.6 & 13 & 7 \\
\hline 3 & Attitude & 5 & 8 & 10 & 7 \\
\hline 4 & People & 3 & 3 & 9 & 6 \\
\hline 5 & $\begin{array}{l}\text { Astronomical } \\
\text { objects }\end{array}$ & 3 & 6.5 & 11 & 9 \\
\hline 6 & Features & 1.7 & 4 & 7 & 6 \\
\hline 7 & Sky & 1.7 & 2 & 2 & 2 \\
\hline 8 & $\begin{array}{l}\text { Natural } \\
\text { phenomena }\end{array}$ & 1.2 & 1 & 2 & 1 \\
\hline 9 & Nourishment & 1.2 & 2.5 & 2 & 6 \\
\hline 10 & Relief & 1 & 1 & 2 & 6 \\
\hline
\end{tabular}


End of Table 4

\begin{tabular}{lllccc}
\hline $\mathbf{1}$ & \multicolumn{1}{c}{$\mathbf{2}$} & $\mathbf{3}$ & $\mathbf{4}$ & $\mathbf{5}$ & $\mathbf{6}$ \\
\hline 11 & Work & 1 & 2,7 & 2 & 4 \\
\hline 12 & $\begin{array}{l}\text { Agricultural } \\
\text { land }\end{array}$ & 1 & 4 & 2 & 2 \\
\hline 13 & Flora & 1 & 2.3 & 3 & 5 \\
\hline 14 & Water & 0.8 & - & 2 & - \\
\hline 15 & Natural & 0.7 & 2 & 4 & 1
\end{tabular}

phenomena and elements

\begin{tabular}{lllcll}
\hline 16 & Comparison & 0.6 & 2 & 7 & 1 \\
\hline 17 & Motherland & 0.5 & 0.4 & 1 & 2 \\
\hline 18 & Life & 0.5 & 2 & 1 & 1 \\
\hline 19 & Country & 0.5 & 0.2 & 1 & 1 \\
\hline 20 & Land, part of & 0.5 & - & - & -
\end{tabular}
the land

\begin{tabular}{llllll}
\hline 21 & Building & 0.4 & 1 & 1 & 1 \\
\hline 22 & Tools, & 0.4 & - & - & -
\end{tabular}
machinery

\begin{tabular}{|c|c|c|c|c|c|}
\hline 23 & Settlement & 0.3 & - & 1 & 1 \\
\hline 24 & The last refuge & 0.3 & 0.4 & 1 & - \\
\hline 25 & Reminiscence & 0.3 & 1.5 & 1 & - \\
\hline 26 & Harvest & 0.3 & 1.3 & - & 3 \\
\hline & Fauna & 0.2 & - & - & 1 \\
\hline 28 & Time & 0.1 & 0.4 & - & - \\
\hline 29 & Happiness & - & 0.2 & - & - \\
\hline & World & 0.1 & - & - & 1 \\
\hline 31 & $\begin{array}{l}\text { Form of } \\
\text { management }\end{array}$ & 0.1 & - & 1 & - \\
\hline 32. & $\begin{array}{l}\text { Feelings and } \\
\text { emotions }\end{array}$ & 0.1 & - & - & 1 \\
\hline 33 & Part of the body & 0.1 & - & - & 1 \\
\hline 34 & Personalities & 0.1 & - & - & - \\
\hline 35 & Season & 0.1 & - & - & - \\
\hline 36 & Nature & 0.1 & - & - & - \\
\hline 37 & Disease & 0.1 & - & - & - \\
\hline & Color & - & 3 & - & $\overline{2}$ \\
\hline 39 & Landscape & - & 0.2 & - & 1 \\
\hline 40 & $\begin{array}{l}\text { Depths of the } \\
\text { earth, mineral } \\
\text { resources }\end{array}$ & - & 0.2 & 1 & - \\
\hline
\end{tabular}


End of Table 4

\begin{tabular}{llllll}
\hline $\mathbf{1}$ & \multicolumn{1}{c}{$\mathbf{2}$} & $\mathbf{3}$ & $\mathbf{4}$ & $\mathbf{5}$ & $\mathbf{6}$ \\
\hline 41 & Age & - & 0.2 & - & - \\
\hline 42 & Family & - & 0.2 & - & - \\
\hline 43 & $\begin{array}{l}\text { Units of the } \\
\text { universe }\end{array}$ & - & 0.2 & - & - \\
\hline 44 & $\begin{array}{l}\text { Religious } \\
\text { notions }\end{array}$ & - & 0.2 & - & - \\
\hline 45 & $\begin{array}{l}\text { Agricultural } \\
\text { activities }\end{array}$ & - & - & 6 & - \\
\hline 46 & Peace & - & - & 1 & 27 \\
\hline $\begin{array}{l}\text { The total number of } \\
\text { the zones }\end{array}$ & 37 & 31 & 27 & \\
\hline
\end{tabular}

Gestalt kernels of associative stimulus fields of LAND (ЗЕМЛЯ) are the two largest zones in quantity. They are not stable and identical for decades, they change in the lingual consciousness of respondents in accordance with changes which are caused by various extralingual factors. Gestalt nuclei change in both qualitative and quantitative composition. So, referring to the experiment, conducted in the 1970s' among Ukrainian respondents, the nucleus includes the 'Characteristics' zone, $68 \%$, 'Soil', $5 \%$, 'Attitude', $5 \%$; in 2004 - 'Characteristics', 45\%, 'Attitude', $8 \%$ (dictionary data reflect the results of experiments in 1998-1999 so we submit them as followings; in 2000 - 'Soil', $13 \%$, 'Characteristics', $11 \%$, 'Astronomical Celestial Bodies', $11 \%$; in 2012 - 'Characteristics', $23 \%$, 'Celestial Bodies', $9 \%$. Thus, the 'Characteristics' zone is present in all associative field kernels. But its rank and quantity differ considerably: from the first place in the gestalt of the associative field of the stimulus obtained in the experiment in 1970s and the vast majority of reactions that describe the earth from different directions; more than two thirds of the total number of reactions (68\%), keeping the first position, however, significantly reduce the volume of reactions $(45 \%)$ in the gestalt associative field in the results in the dictionary of 2004 to the second place in the gestalt of the associative field obtained at the turn of the century and the smallest number of reactions, which is slightly increased $(23 \%)$ in the gestalt of the associative field obtained in 2012, which made it possible to take first place among other zones.

Also with the changed qualitative composition of the zone during this time, for example, the most frequent associations of characteristics in 1970s were the LAND (ЗЕМЛЯ) - чорна (black) (196), кругла (round) (88), рідна (native) (39), багата (rich) (38), etc.; according to the dictionary edited in 2004 - LAND (ЗЕМЛЯ) рідна (native) (46), кругла (round) (38), родюча (fertile) (24), чорна (black) (21); in 2000 - LAND (ЗЕМЛЯ) - кругла (round) (6), рідна (native) (2), чорна (black) (2), жива; (alive); in 2012 - LAND (ЗЕМЛЯ) - чорна (black) (8), кругла (round) (8), плодовита (fertile) (2), тепла (warm). The second position in the nucleus of the gestalt of the associative field of the 1970s with the same volume $(5 \%)$ is 
occupied by the 'Soil' and 'Attitude' zones. The 'Attitude' zone $(8 \%)$ with somewhat larger volume is also available in the nucleus of the associative field gestalt in 2004. The associations of the latter zone are mostly reflected by the perceptions of the Ukrainian respondents about the land and a respectful attitude towards it, for example: LAND (ЗЕМЛЯ) - мати (mother) (30), годувальниия (nurse) (6), багатство (wealth) (in 1970s); LAND (ЗЕМЛЯ) - багатство (wealth) (8), годувальниия (nurse) (7), матінка (титту) (5), mother (2), мати (mum / mom), etc. (2004).

In the nuclei of associative fields obtained in 2000 and 2012, the second position is occupied by the 'Celestial Bodies' zone with an area of $11 \%$ and $9 \%$, respectively, represented by reactions of LAND (ЗЕМЛЯ) - планета (planet) (11) (2000); Ukrainian respondents represent the perception of the stimulus of the EARTH (the EARTH (ЗЕМЛЯ) - планета (planet) (5), Bсесвim (Universe) (3), космос (Space) (2012)) as one of the astronomical objects.

In general, while comparing gestalts of associative fields of the stimulus LAND (ЗЕМЛЯ) we may see full simularity in the structure of the associative fields, in particular, the first 18 zones are similar for all gestalts. They reflect the main ways of associating. At the same time, the range and extent of these zones are different. For example, among Ukrainian respondents reactions there is an association the SKY (zone 'SKY' (1.7\%; $2 \% ; 2 \% ; 2 \%)$ ), the extent of the corresponding zones is approximately the same for all gestlts. Although, their ranges are different. This reaction shows the constant for the culture opposition LAND (ЗЕМЛЯ) - the SKY, that is rather ancient by its origin and is still topical nowadays.

The other zone was found for three gestalts of the associative field 'Final Abode'. It has changed its extent for increasing and now it is represented by different associations: LAND (ЗЕМЛЯ) - могила (grave), похорон (funeral), смерть (death) $(0.3 \%$; 1970s); LAND (ЗЕМЛЯ) - кладовище (cemestry), пухом (rest in peace) $(0.4 \% ; 2004)$; LAND (ЗЕМЛЯ) - труна (hearse) $(1 \%$; 2000).

Time passed, and the extent of zones 'Motherland' and 'Country' has increased. To a certain extent, it demonstrates the importance of this way of associating, the tendency to connect the concept LAND (ЗЕМЛЯ) with place of birth, native land, a certain country. In most of cases respondents mentioned just Ukraine. For example, the zone 'Motherland' is represented in gestalts by the following associations: LAND (ЗЕМЛЯ) - батьківщина (motherland) (3), вітчизна (fatherland) (0.5\%; 1970s); LAND (ЗЕМЛЯ) - батьківщина (motherland) (2) $(0,4 \%$; 2004); LAND (ЗЕМЛЯ) - Батьківщина (motherland) (1\%; 2000); LAND (ЗЕМЛЯ) - батьківщина (motherland) (2) (2\%; 2012). Associations of "Country" zone (they are: LAND (ЗЕМЛЯ) - Україна (Ukraine) (0,5\%; 1970s); LAND (ЗЕМЛЯ) - Украӥна (Ukraine) ( 0.2\%; 2004); LAND (ЗЕМЛЯ) - краӥна (country) (1\%; 2000); LAND (ЗЕМЛЯ) - Україна (Ukraine) (1\%; 2012)) mainly show the comprehending land as their native land, Ukraine, by the Ukrainian respondents. It was observed during the whole period of conducting the research, although in times of creating the associative dictionary by $\mathrm{N}$. Butenko 
((1979), the one, we use in our research, as well) Ukraine was yet included to the USSR as a republic.

Associations filling in the zone 'Reminiscences' demonstrate the closest connection with its stimulus, with which they form a set phrase. For example, the associations belonging to the gestalt of the associative field stimulus ЗЕМЛЯ (LAND) in 1970s (LAND (ЗЕМЛЯ) - воля (freedom), гуде (the hlebe) is singing); in the gestalt of the associative field of stimulus LAND in 2004 (LAND (ЗЕМЛЯ) - $i$ воля (and freedom) (2), $і$ небо (and the sky) (2), в ілюмінаторі (through the luminaire), в огне (рос.) (in the fire (Rus.)), воля (freedom), пухом (rest in peace)), in the gestalt of the associative field of the stimulus LAND in year of 2000 (LAND (ЗЕМЛЯ) - воля (freedom), reflect the embodied in the consciousness of the Ukrainian respondents culturally and historically important information. For example, reactions with stimulus LAND (ЗЕМЛЯ) - воля (freedom), $і$ воля (and freedom) are connected with the nominations of the official organ, the newspapers of political movements, well-known from the history of the beginning of the $20^{\text {th }}$ century; LAND (ЗЕМЛЯ) - zуде (is rumbling) refers to the title of the story by the famous Ukrainian writer Oles Honchar "Earth Is Rumbling" (1946); LAND (ЗЕМЛЯ) - в ілюмінаторi (through the porthole) - represents the title of the popular song of the pop-group Zemlyany in the middle of 1990s. There are also several reactions representing fraseological units or their parts, for example: LAND (ЗЕМЛЯ) - пухом (rest in peace) (good remembering of a died person).

Gestalts constructed based on the associative fields of a bigger size, have more branchy structure hovewer there exist certain zones in each gesture, which are pecular for each of them only. In particular, they are as follows: in the gestalt of the associative field of the stimulus ЗЕМЛЯ (LAND) in 1970s these zones are 'Season of the year' (LAND (ЗЕМЛЯ) - весна (spring)), 'Personalities' (LAND (ЗЕМЛЯ) - Кобилянська (Kobylyanska), the Ukrainian writer (femail), the author of the story 'Land' (1901)), 'Nature' (LAND (ЗЕМЛЯ) - природа (nature)), 'Disease' (LAND (ЗЕМЛЯ) - стовбняк (tetanus)); in the gestalt of the associative field of the stimulus LAND in 2004 the above mentioned zones are 'Age' (LAND (ЗЕМЛЯ) 4,6 млрд. років (4,6 bln уеars)), 'Family' (LAND (ЗЕМЛЯ) - родина (family)), 'Bodies of the Universe' (LAND (ЗЕМЛЯ) - атом (atom)), 'Religious Concepts' (LAND (ЗЕМЛЯ) - гpix (sin)); in the gestalt of the associative field of the stimulus LAND in 2000 these zones are 'Agricultural Activity' (LAND (ЗЕМЛЯ) саджати (to plant)), 'World' (LAND (ЗЕМЛЯ) - мир (world)). Hence, the described zones define the ways of associating ЗЕМЛЯ (LAND) stimulus by respondents; they were significant in forming of images of language consciousness referring to it for a certain period of time.

The results of analys is of associative stimulus fields of the word ЗЕМЛЯ (LAND), which were obtained due to the free associative experiments among the Russian respondents for the analogous period of time - from 1970s to 2012, are presented in the following table (see Table 5). 
Table 5

The gestalt structure of the associative fields of the stimulus ЗЕМЛЯ (LAND) according to dictionaries and free associative experiments in the Russian language

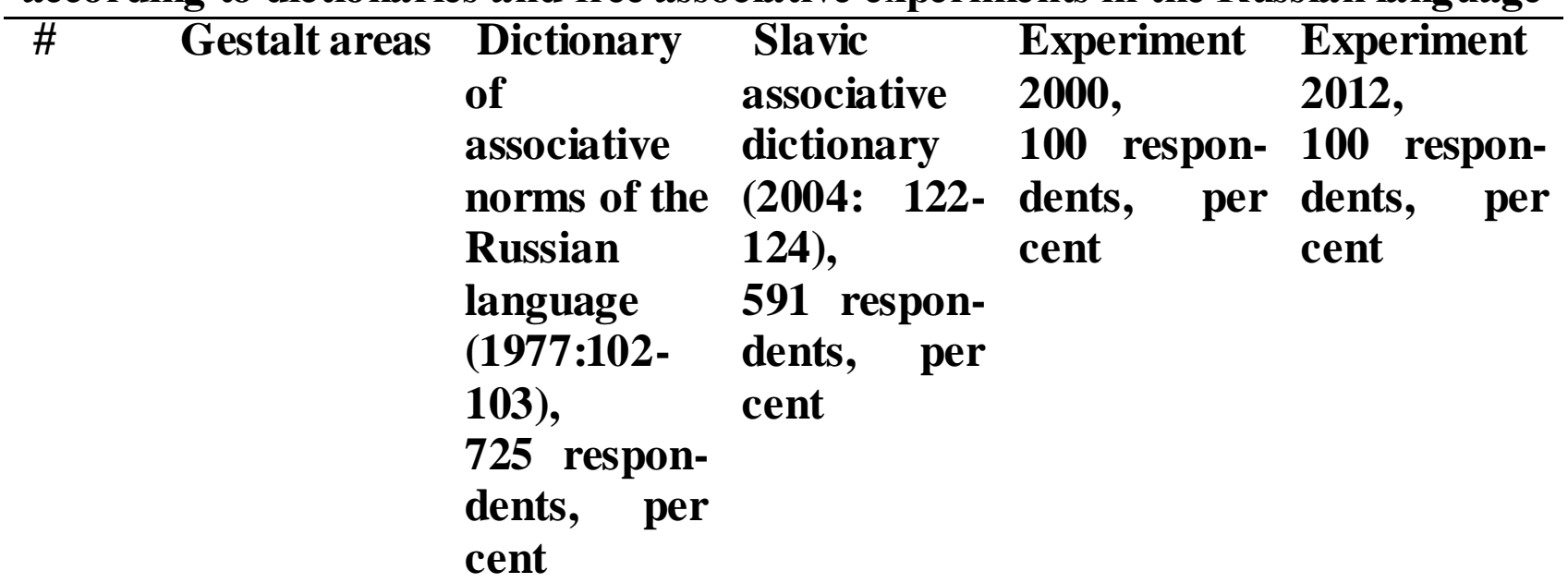

\begin{tabular}{cccccc}
\hline $\mathbf{1}$ & $\mathbf{2}$ & $\mathbf{3}$ & $\mathbf{4}$ & $\mathbf{5}$ & $\mathbf{6}$ \\
\hline 1 & Characteristics & 41 & 30 & 8 & 14
\end{tabular}

\begin{tabular}{lllllc}
\hline 2 & $\begin{array}{l}\text { Astronomical } \\
\text { objects }\end{array}$ & 10 & 12 & 17 & 24 \\
\hline 3 & Agricultural land & 6.5 & 1.2 & 6 & 2
\end{tabular}

\begin{tabular}{rlcccc}
\hline 4 & People & 6 & 3 & 1 & 3 \\
\hline 5 & Sky & 5 & 8 & 16 & 7 \\
\hline 6 & Attitude & 5 & 4.2 & 1 & 3 \\
\hline 7 & Reminiscence & 4 & 3 & 4 & 4 \\
\hline 8 & World & 4 & 0.6 & 4 & 1 \\
\hline 9 & Features & 3 & 4 & 6 & 8 \\
\hline 10 & Soil & 2 & 4,6 & 11 & 10 \\
\hline 11 & Natural & 2 & 6.5 & 5 & 3
\end{tabular}
phenomenon

\begin{tabular}{llcccc}
\hline 12 & Comparison & 1.6 & 6 & 8 & 4 \\
\hline 13 & Flora & 1.5 & 3.7 & 10 & 6 \\
\hline 14 & Motherland & 1 & 4 & 1 & 1
\end{tabular}

\begin{tabular}{llcccc}
\hline 15 & $\begin{array}{l}\text { Land, part of the } \\
\text { land }\end{array}$ & 1 & 0.5 & - & 2 \\
\hline 16 & Color & 1 & 0.3 & - & 1 \\
\hline 17 & Actions & 0.8 & 0.2 & - & - \\
\hline 18 & Building & 0.6 & 1.2 & - & - \\
\hline 19 & Nourishment & 0.4 & 1.7 & - & - \\
& & & & & - \\
\hline 20 & Country & 0.4 & 0.5 & - & - \\
\hline 21 & Settlement & 0.4 & 0.2 & - & \\
\hline
\end{tabular}


End of Table 5

\begin{tabular}{|c|c|c|c|c|}
\hline 1 & 3 & 4 & 5 & 6 \\
\hline 22 Road & 0.3 & 0.2 & - & - \\
\hline 23 Harvest & 0.3 & 0.5 & - & - \\
\hline 24 The last refuge & 0.3 & - & - & 1 \\
\hline $\begin{array}{ll}25 & \begin{array}{l}\text { Geographical } \\
\text { objects }\end{array} \\
\end{array}$ & 0.3 & - & - & - \\
\hline 26 Personalities & 0.3 & - & - & - \\
\hline 27 Work & 0.2 & 0.5 & - & - \\
\hline 28 Life & 0.2 & 1 & - & - \\
\hline $\begin{array}{l}29 \text { The age of the } \\
\text { person }\end{array}$ & 0.2 & - & - & - \\
\hline 30 Tools, machinery & 0.2 & - & - & - \\
\hline 31 Season & 0.2 & - & - & - \\
\hline $32 \begin{array}{l}\text { Form of } \\
\text { management }\end{array}$ & 0.2 & - & - & - \\
\hline 33 Time & 0.2 & - & - & - \\
\hline 34 Relief & - & 0.6 & - & - \\
\hline 35 Pond & - & 0.4 & - & 1 \\
\hline 36 Fauna & - & 0.3 & - & 1 \\
\hline $\begin{array}{l}37 \text { Tangible assets / } \\
\text { property }\end{array}$ & - & 0.3 & - & - \\
\hline 38 Religious notions & - & 0.2 & 1 & - \\
\hline 39 Nature & - & 0.2 & - & 1 \\
\hline $\begin{array}{ll}40 & \text { Depths of the } \\
\text { earth, mineral } \\
\text { resources }\end{array}$ & - & 0.2 & - & - \\
\hline 41 Civilization & - & 0.2 & - & - \\
\hline $42 \begin{array}{l}\text { Agricultural } \\
\text { activities }\end{array}$ & - & - & 1 & 1 \\
\hline 43 Price & - & - & 1 & 1 \\
\hline $\begin{array}{l}\text { The total number of } \\
\text { the zones }\end{array}$ & 31 & 33 & 18 & 23 \\
\hline
\end{tabular}

The comparison of the nuclei of the associative fields has shown that the zones 'Characteristics', $41 \%$ and 'Celestial Bodies', $10 \%$ have the largest volume in the gestalt of the associative field of the stimulus of the ЗЕМЛЯ (ЕАRTH) in the 70ies. In 2004 the gestalt of the associative stimulus field of the word ЗЕМЛЯ (LAND) has the same zones in particular the 'Characteristics' one, $30 \%$ and 'Celestial Bodies', $12 \%$, however, the volumes of these zones have changed: 
towards the $11 \%$ decrease in the 'Characteristics' zone and towards a slight increase of $2 \%$ of the zone 'Celestial Bodies'.

In 2000 the gestalt of the associative field of the stimulus ЗЕМЛЯ (LAND) shows that the area of 'Celestial Bodies' , $17 \%$ occupies the first volume place, the second one- the Sky zone $16 \%$; in year 2012 the associative field gestalt of the 'Celestial Bodies' zone is $24 \%$, the zone 'Characteristics' - $14 \%$. Thus, among Russian respondents there is a tendency to perceive the earth as a planet in space among other objects, for example: the EARTH (ЗЕМЛЯ) - планета (the Planet) (40), the Луна (Moon) (11), Вселенная (the Universe) (4), космос (the Space) (4), солние (the Sun) (2), планета Земля (the Planet Earth) (in the 70s $10 \%$ ); the ЕARTН (ЗЕМЛЯ) - планета (the planet) (53), Луна (the moon) (5), Вселенная (the universe) (4), космос (the space) (2), галактика (the galaxy), голубая планета (the blue planet), шар земной (the planet globe) (in 2004, $12 \%$ ); the ЕАRТН (ЗЕМЛЯ) - планета (the Planet) (13), планеты (the Planets) (2), Вселенная (the Universe), космос (Space) (2000, 17\%); ЕARTH (ЗЕМЛЯ) планета (the planet) (22), Солние (the sun) (2) (in 2012, $24 \%$ ).

This tendency is also supported by the reactions of other zones, for example, in the 70s the most frequent association of the 'Characteristics' zone was the LAND (ЗЕМЛЯ) - родная (native) (66); in 2000 the LAND (ЗЕМЛЯ) - круглая (is round) (3); in 2004 the LAND (ЗЕМЛЯ) - круглая (round) (79), in 2012 it is also кругля (round) (6).

In comparison with the research results of the experimental materials among the Ukrainian respondents, it turned out that this association has been more powerful for Russian respondents, whereas for Ukrainians, even in the context of a gradual decrease, the descriptive perceptions and the identification of comprehensive characteristics are significant.

In general in the gestalt of the stimulus of the word ЗЕМЛЯ (LAND) there are fifteen identical zones in the Russian language and they are the largest in volume. But their volume and rank in the structures of the gestalt differ. For example, the constant orientation of association is the perception of the earth in opposition to the sky, represented by the 'Sky' zone with the corresponding volume: the EARTH (ЗЕМЛЯ) - небо (the sky) (39) (in 70's, 5\%); the ЕARTH (ЗЕМЛЯ) - небо (the sky) (50) (in 2004, 8\%); the ЕARTH (ЗЕМЛЯ) - небо (the sky) (16) (in 2000, 16\%); the EARTН (ЗЕМЛЯ) - небо (the sky) (7) (in 2012, 7\%).

Another tendency of association is the perception of the land as the SOIL (the 'Ground' zone). In the 21-st century it has become more significant among the Russian respondents as it is evidenced by an increase in this area: the LAND (ЗЕМЛЯ) - чернозем (the chernozem) (9), почва (the soil) (8) (in 1970's), $2 \%$ ); the LAND (ЗЕМЛЯ) - почва (the soil) (14), чернозем (the chernozem) (4), песок (the sand) (2), глина (the clay), грунт (soil) ( in 2004, 4.6 \%); the LAND (ЗЕМЛЯ) почва (the soil) (5), чернозем (the chernozem) (2), почва (the soil) (in 2000, $10 \%$ ); the LAND (ЗЕМЛЯ) - почва (the soil) (8), песок (the sand) (in 2012, $10 \%$ ).

The associations of 'Attitude' zones testify that there is the respectful attitude among Russian respondents towards the word land laid down in culture. Some of 
reactions that embody the perception of the earth as mother, breadwinner are more typical for the lingual consciousness of Russians in 1970s: the EARTН (ЗЕМЛЯ) матушка (mother) (7), кормилица (breadwinner) (5), богатство (the wealth) (2), наш дом (our home) (2), кольбель разума (the cradle of the mind), моя любимая (my close person), моя родная (my beloved) (in 1970s, 5\%); the ЕАRTН (ЗЕМЛЯ) - мать (mother) (16), кормилица (breadwinner) (6), уважай (respect), это хлеб нam (it is our bread) (in 2004, 4,2\%); the EARTH (ЗЕМЛЯ) - мamb (mother) (in 2000, 1\%); the EARTH (ЗЕМЛЯ) - матушка (dear mother) (2), кормилица (breadwinner) (in 2012, 3\%).

In the 'Reminiscence' zone some reactions are similar to the responses among the Ukrainian respondents, in particular, the LAND (ЗЕМЛЯ) - $i$ воля (and freedom), в иллюминаторе (in the illuminator), пухом (rest in peace), which is explained by the common historical and cultural heritage. Individual associations are the reflection of events. They are significant for a particular historical period. For example, the reaction of the LAND (ЗЕМЛЯ) - $я$ своих провожаю питомиев (I am taking my pets off) (2) is given among the Russian respondents in 1970s that is an extract from the famous song "I am Earth!" written by V. Mudareli and E. Dolmatovsky and performed by Olga Voronets, a popular singer of that time.

The association of the LAND (ЗЕМЛЯ) - Санникова 'Sannikov' is present in almost all associative fields of this stimulus because it reflects the name of the work by the famous Russian Soviet writer V. Obruchev. Another association of the LAND (ЗЕМЛЯ) - малая (small), Брежнев (Brezhnev) (in 2004) presents another literary work 'The Minor Land' (1978) by L. Brezhnev, Secretary General of the Soviet Union's Central Committee of the CPSU.

Like the Ukrainian respondents, Russians create incentives for the word LAND (ЗЕМЛЯ) with their native land, the motherland, represented in the corresponding zones by the reactions of the LAND (ЗЕМЛЯ) - Родина (Motherland) (7) (in 1970's, 1\%); LAND (ЗЕМЛЯ) - Родина (Motherland) (21), родина (Motherland) (2) (in 2004, 4\%); LAND (ЗЕМЛЯ) - Родина (Motherland) (in 2000, 1\%); LAND (ЗЕМЛЯ) - родина (Motherland) (in 2012, 1\%), all of which are almost the same in volume but only those that are in the associative field of year 2004 are dominant.

The zones 'Country' are available only in two gestalts, represented by reactions LAND (ЗЕМЛЯ) - страна (country) (2), Зеландия (Zealand) (in 1970s, 0.4\%); LAND (ЗЕМЛЯ) - Россия (Russia), России (of Russia), страна (the country) (in $2004,0.5 \%$ ), which are more identifiable with their country in the associative field in 2004, after the collapse of the USSR.

Some zones are specific to a specific gestalt, for example, in the Gestalt of the 1970s, for example, the 'Season' (LAND (ЗЕМЛЯ) - весна (spring) (2)), the 'Age' (LAND (ЗЕМЛЯ) - cmapocmb (being old)), the 'Tools, Mashinery' (LAND (ЗЕМЛЯ) - трактор (tractor)), 'Form of Management' (LAND (ЗЕМЛЯ) колхоз (collective farm (2)), 'Time' (LAND (ЗЕМЛЯ) - день (day)); in Gestalt in 2004 - "Natural Resources' (LAND (ЗЕМЛЯ) - недра (deposits), 'Civilization' (LAND (ЗЕМЛЯ) - цивилизация (civilization), 'Property' (LAND (ЗЕМЛЯ) деньги (топеу), собственность (property). The relation to the land as a sale 
process and sale object can be also traced in the responses of Russian respondents in 2012. The LAND (ЗЕМЛЯ) - иена (рrice) is a part of the zone with the same name. The recent reactions reflect the changes in the lingual consciousness of the Russian respondents associated with the economic processes in the country in the 21 st century.

\section{Conclusions}

Lingual consciousness is a dynamic phenomenon. The images of the lingual consciousness, which are not in the stimulus, can be changed over the time due to the influence of extralingual factors. The method of associative gestalt represents the particular structure of each associative field, the quantitative and qualitative components of all branches, it enables us to trace all, even the smallest noticeable changes which are especially important in the study of closely related languages or one language but in dynamics.

The stimulus concept ЗЕМЛЯ (ЕАRTH) / ЗЕМЛЯ (ЕАRTH) is a culturally significant concept both for Ukrainians and Russians. These words are common in their origin and have similar lexical meanings. Their psycholinguistic significance is also quite close which shows that they belong to the same areas in associate fields of gestalt but their qualitative and quantitative components, the presence of some zones in a certain gestalt, changes occurring at a certain period of time, indicate the linguistic consciousness dynamics.

We see the prospects in the study of the dynamic aspect of the native speakers' linguistic consciousness both individually and in comparison with other ones in order to manifest the common and distinctive features.

\section{References}

Жайворонок В. В. Знаки української етнокультури: Словник-довідник / В. В. Жайворонок. К.: Дов іра, 2006.

Марковина И. Ю., Данилова Е. В. Специфика языкового сознания русских и американцев: опыт построения «ассоциативного гештальта» текстов оригинала и перевода // Языковое сознание и образ мира / Отв. ред. Н. В. Уфимцева. М.: Институт языкознания РАН, 2000. С. 116-132.

Степанов Ю. С. Константы: Словарь русской культуры: Изд. 2-е, испр. и доп. М.: Академический Проект, 2001.

\section{References (translated and transliterated)}

Zhaivoronok, V. V. (2006) Znaky Ukrayinckoyi Etnokultury: Slovnyk-Dovidnyk [Signs of the Ukrainian Ethnoculture: Dictionary-Reference Book]. Kyiv: Dovira.

Markovina, I. U., Danilova, E. V. (2000) Spetsifika jazyko vogo soznaniya russkih i amerikantsev: opit postrojenija "assotsiativnogo geshtalta" tekstov originala i perevoda [The peculiarity of the lingual consciousness of Russians and Americans: the experience of constructing an "associative gestalt" of the original and translation texts]. In: Yazykovoye Soznaniye i Obraz Mira, (pp. 116-132) .N. Ufimtseva, Ed. Moscow: Institute of Linguistics of the Russian Academy of Sciences.

Stepanov, Yu. S. (2001). Konstanty: Slovar Russkoy Kultury: $2^{\text {nd }}$ edition [Constants: Dictionary of the Russian Culture]. Moscow: Akademicheskiy Proekt. 


\section{Джерела}

Бутенко Н. П. Словник асоціативних норм української мови. Львів : Вища школа, 1979.

Ожегов С., Шведова $\mathrm{H}$. Толковый словарь русского языка. Режим доступа: https://classes.ru/all-russian/russian-dictionary-Ozhe gov-term-10012.htm

САC - Славянский ассоциативный словарь: русский, белорусский, болгарский, украинский / Н. В. Уфимцева, Г. А. Черкасова, Ю. Н. Караулов, Е.Ф. Тарасов. М., 2004.

САНРЯ - Словарь ассоциативных норм русского языка / Под ред. А. А. Леонтьева. М.: Издво Моск. ун-та, 1977.

Словник української мови: Академічний тлумачний словник (1970-1980). Т. 3. С. 557.

\section{Sources}

Butenko, N. P. (1979). Slovnyk Asotsiatyvnykh Norm Ukrayinckoyi Movy [Dictionary of the Associative Norms of the Ukrainian language]. Lviv: Vyshcha Shkola.

Dictionary of the Ukrainian Language. (1970-1980). Vol. 3, P. 557.

Ozhegov, S., Shvedova, N. The Explanatory Dictionary of the Russian Language. Retrieved from: https://classes.ru/all-russian/russian-dictionary-Ozhegov-term-10012.htm

Slavyanskiy Assotsiativnyi Slovar: Russkiy, Belorusskiy, Bolgarskiy, Ukrainskiy (2004) [Slavic Associative Dictionary: Russian, Belorusian, Bulgarian, Ukrainian]. N. Ufimtseva, G. Cherkasova, Yu. Karaulov, Ye. Tarasov, (Eds). Moscow.

Slovar Assocziativnyh Norm Russkogo Yazyka (1977). [Dictionary of Associative Norms of the Russian Language]. A. A. Leontyev, Ed. Moscow: Moscow University. 